\title{
BESENYŐ JÁNOS
}

\section{Az erdőtűz mint a terror egyik új formája}

2016. november 18. és 26. között Izrael 220 különböző pontján gyulladtak ki az erdők. Az izraeli tüzoltóság nem volt képes egyedül megfékezni a tüzeket, ezért a hadsereg és a rendőrség alakulatait is igénybe kellett venni, sőt több ezer civil önkéntes is csatlakozott a tüz elleni harchoz. Mivel az izraeli tüzoltóság eszközei elégtelennek bizonyultak az egymás után fellobbanó tüzek megfékezésére, a miniszterelnök, Benjamin Netanjahu nemzetközi támogatást kért és kapott. Ciprus, Görögország, Olaszország, Oroszország és Törökország néhány órán belül egységeket küldött Izraelbe. Később más államok is - köztük a Palesztin Hatóság is - csatlakoztak a nemzetközivé váló mentőakcióhoz. A nyolc napon keresztül tartó akcióban több mint ezerhétszáz tüzet fékeztek meg, amelyek azonban jelentős károkat okoztak. Az izraeli jelentések 133 sebesültről és hatalmas anyagi károkról tudósítottak.

A rendkívül száraz és szeles időszak miatt eleinte mindenki a szélsőséges időjárást hibáztatta, de hamarosan kiderült, hogy több esetben szándékos gyújtogatás történt, amelynek során arab származású izraeli állampolgárok, illetve a Palesztin Hatóság területén élők benzinnel gyújtották fel a nagy szárazság miatt könnyen lángra lobbanó erdőket. Az izraeli hatóságok nyomozást indítottak, ennek során huszonöt tüzesetről egyértelmüen kiderült, hogy szándékos gyújtogatás okozta, emiatt harmincöt embert vettek örizetbe gyújtogatás vádjával. Bár nem ez volt az első szándékos gyújtogatás, amit a palesztinok követtek el, de ennyire szervezett és hatékony akciót eddig nem voltak képesek kivitelezni. Az eset már csak azért is figyelemfelkeltő, mivel az al-Kaida 2012-ben az általa kiadott Inspire magazinban egy hosszabb cikkben értekezett arról, hogy az erdőtüzeket hogyan lehetne az Egyesült Államok elleni terrortámadásokra felhasználni. Úgy gondolom, hogy az ötletet a palesztinok ,,sikerre vitték", ezért számíthatunk annak újabb felbukkanására.

\section{A tüz mint fegyver és a terror eszköze}

A történelem folyamán több alkalommal is használták a tüzet az ellenség megsemmisítésére, majd később különböző terrortámadásokhoz is. Brian A. 
Jackson és David R. Frelinger mindezt jól szemléltetik az 1980 és a 2005 közötti terrortámadások eszközeit vizsgáló tanulmányukban. A szerzők kutatásai alapján az ötezer bekövetkezett terrortámadás tizenegy százalékát (550 eset!) követték el tüz (gyújtogatás, Molotov-koktél stb.) alkalmazásával a terroristák. ${ }^{1}$ Egy másik elemzés szerint nemzetközi szinten 1968 és 2005 között ötvenöt olyan terrorszervezetről tudunk, amely a támadásai során akár önállóan, akár más eszközökkel kombinálva, hatékonyan alkalmazta a tüzet. ${ }^{2}$

Az elmúlt évtizedekben ez az eszköz több környezetvédelemmel és állatvédelemmel foglalkozó radikális csoport fegyvertárába is bekerült, amelyek nemcsak a velük szemben állók anyagi javainak tüzzel elpusztítását (személygépkocsik, lakások, üzlethelyiségek stb.), de a génmódosított ültetvények felgyújtását, vagy éppen a szándékos erdőtüzek okozását is elfogadható eszköznek tekintik. ${ }^{3}$ A tủz ugyanis egy rendkívül hatékony fegyver, ami szinte megállíthatatlan, és amíg gyúlékony anyag és levegő található a környezetében, pusztításra képes, és mindent el is pusztít. Az emberek többsége, ha körülölelik a lángok, nem gondol a védekezésre, sem a tervszerüségre, egyszerüen pánikba esve kezd menekülni. De nemcsak a lángok veszélyesek, hanem a füst is, amely legalább olyan kegyetlen gyilkos, mint a tüz, ráadásul a terroristák ellen esetleg fellépők ellen is felhasználható. ${ }^{4}$ A tüzet azért is részesítik előnyben a terroristák, mert annak használatához nem szükséges hosszan tartó kiképzés, nincs nagy költsége, és viszonylag kevés emberrel végrehajtható, de a megfelelő körülmények (időjárás, szél stb.) esetén rendkívül hatékony, nagy rombolásra képes. Gondoljuk el azt a helyzetet, amikor egy sikeres gyújtogatás után nemcsak az otthonunk, de a nekünk táplálékot adó földek, vagy a pihenésünket szolgáló erdők is megsemmisülnek, ezek pótlása csak nagy anyagi ráfordítással és hosszú idő alatt érhető el. A tüz használata többféleképpen történhet. Lehet sima gyújtogatással, amikor is könnyen éghető anyagokat használnak a terroristák, de próbálkozhatnak gázzal vagy más jól éghető anyaggal (gázolaj stb.) töltött tartályokkal is. Példá-

\footnotetext{
1 Brian A. Jackson - David R. Frelinger: Rifling Through the Terrorists' Arsenal Exploring Groups' Weapon Choices and Technology Strategies. Rand Corp., 2007 http://www.rand.org/content/dam/rand/pubs/working_papers/2007/RAND_WR533.pdf

2 Robert A. Baird: Title: Pyro-Terrorism. The threat of arson induced forest fires as a future terrorist weapon of mass destrucion. 2005. http://www.dtic.mil/dtic/tr/fulltext/u2/a509220.pdf

3 U.S. Senate: Statement of John Lewis Oversight on Eco-terrorism specifically examining the Earth Liberation Front (ELF) and the Animal Liberation Front (ALF). http://www.iwar.org.uk/cyberterror/resources/eco-terror/lewis.htm ; Daniel Schorn: Burning Rage. CBS News, 2005. Nov. 10. http://www.cbsnews.com/news/burning-rage/

4 Rendvédelmi erők zavarása, a terroristák álcázása stb.
} 
ul amikor teli tankert vezetnek neki egy kormányzati vagy polgári célpontnak. ${ }^{5}$ Az elkövetők lehetnek magányos farkasok, de jól szervezett csoport is állhat a gyújtogatások hátterében, amelynek tagjai egyszerre több helyen gyújtogatnak, így a védekezők ereje szétforgácsolódik. Illetve a gyújtogatást más módszerekkel is kombinálhatják (bombák használata, öngyilkos merénylők, támadás a védekezést folytatók ellen stb.), ily módon tovább növekszik a sikeres terrortámadás esélye. Azt se felejtsük el, hogy a terroristák ellen fellépő erőknek nemcsak a fegyveresekkel, de a tủzzel és az azzal járó füsttel is fel kell venniük a harcot, mindez további értékes időt vesz el.

Az egyik legismertebb példa a terrortámadás során a tủz kombinált használatára a Világkereskedelmi Központ ikertornyai elleni 2001. szeptember 11-i támadás, amikor is a terroristák két menetrend szerinti légi járatot vezettek az ikertornyokba, a gépek üzemanyaga berobbanva pedig hatalmas tüzet okozott. A tüz nemcsak az irodaépületben dolgozók egy részét ölte meg szinte azonnal, de az épületek szerkezetét is olyannyira meggyengítette, hogy összeomlottak, ami további százak halálához vezetett. ${ }^{6}$ Bár sikertelenül végződött, de szintén jó példa egy tüzzel végrehajtandó terrortámadásra a kínai China Southern Airlines CZ6901-es járata elleni támadáskísérlet. 2008. március 7-én a kétszáz emberrel felszálló utasszállítón egy ujgur radikális iszlamista csoporthoz tartozó nő gázolajjal tüzet akart gyújtani a mosdóban, amit a legénység akadályozott meg. Ha sikerült volna a támadás, akkor Kína a történelmének legtöbb áldozattal járó terrortámadását könyvelhette volna el. ${ }^{7}$ Sajnos ennél biztosabbra ment a Lashkar-e-Tajiba (LeT) terrorcsoport 2008 novemberében a mumbai Taj Mahal hotelban, amikor is a terroristák az automata fegyvereket, a különböző robbanószereket, a túszejtést, és a tüzet kombinálták a minél több áldozat érdekében. A legtöbb ember emlékezetében azért maradt meg a támadás, mert a televízióban élőben követhették, ahogy a szállodában rekedő civilek megpróbáltak az ablakokon át kimenekülni az épületet elborító láng- és füsttengerből. Ebben az esetben a terroristák straté-

\footnotetext{
5 Egyre inkább úgy tünik, hogy a terroristák nem a kormányzati, rendvédelmi, katonai, hanem a sokkal könnyebben támadható polgári, ,puha” célpontokat támadják, mivel az ilyen típusú eredményes terrorakciók sokkal nagyobb hatást képesek elérni, és viszonylag gyorsan destabilizálnak egy jóléti, a biztonságot alapvető jogként kezelő társadalmat.

6 Ted Walter: Beyond Misinformation. What Science Says About the Destruction of World Trade Center Buildings 1, 2, and 7. Architects \& Engineers for 9/11 Truth, Inc., Berkeley, 2015. http://cafr1.com/ Beyond-Misinformation-2015.pdf ; Federal Emergency Management Agency: World Trade Center Building Performance Study, 2002. https:/www.fema.gov/media-library/assets/documents/3544

7 Fred Burton - Scott Stewart: China: An Outside-the-Box Terrorist Plot? Stratfor, Mar 19, 2008. https://www.stratfor.com/weekly/china_outside_box_terrorist_plot
} 
giai eszközként használták a tüzet - a média közvetítésével pedig megsokszorozták a támadás által keltett hatást. A három napon keresztül tartó támadásban 166 ember vesztette életét. ${ }^{8}$

2012-ben a líbiai Bengáziban lévő amerikai nagykövetséget megtámadók ${ }^{9}$ is többféle eszközt használtak, de mégsem a lövedékek vagy robbanószerek végeztek az amerikai nagykövettel és munkatársaival, hanem a gyújtogatók által keltett lángok és a füst. Ugyanis a támadók felgyújtották azt a villát, ahova Christopher Stevens nagykövet és két társa menekült, így a lángok és a füst miatt kénytelenek voltak a korábban biztonságosnak ítélt menedéküket elhagyni. Az egyikük még kijutott a villából, de a nagykövet és az Egyesült Államok külügyminisztériumának kommunikációs szakembere, Sean Smith füstmérgezésben vesztette életét. ${ }^{10} \mathrm{Az}$ utána következő brutális eseményeket pedig ismerjük. A terroristák hasonló támadást hajtottak végre az ENSZ Sínai-félszigeten állomásozó erői (UN Multinational Force in the Sinai Peninsula) és a Tunéziában lévő amerikai nagykövetség ellen is. Hasonló történt Nigériában is 2013. július 6-án, amikor a Boko Haram emberei felgyújtottak egy iskolát és több, az égő épületből menekülni próbáló diákot, tanárt agyonlőttek. A támadásban negyvenhatan vesztették életüket. ${ }^{11}$ Úgy gondolom, ez a néhány példa is elegendő annak bemutatására, hogy a terrorcselekmények folyamán a támadók képesek hatékonyan használni a tüzet különbözö célpontok ellen.

A gyújtogatással az a legnagyobb gond, hogy szinte kontrollálhatatlan, ezért akár a tüzgyújtót is veszélyeztetheti. De ez még mindig elenyésző kockázatnak tünik az elérhető eredményekhez képest. És ne felejtsük el, hogy az emberek többsége nem kap megfelelö felkészítést arra, mit tegyen, mondjuk egy több ezer föt befogadó pláza esetleges kigyulladásakor. És még nem is

\footnotetext{
8 Joseph W. Pfeifer: Fire as a weapon in terrorist attacks. Combating Terrorist Center, July 23, 2013. https://www.ctc.usma.edu/posts/fire-as-a-weapon-in-terrorist-attacks

9 A támadók az Anszar al-Sharia (AAS), az al-Kaida in Maghreb (AQIM), az al-Kaida in Arabian Peninsula (AQAP), az al-Kaida in Iraq (AQI) és az Abu Abayda Ibn Jarrah Battalion (UJB) terrorista csoportok tagjaiból és a korábbi diktátorhoz, Kadhafihoz lojális erők soraiból kerültek ki.

10 Mike Rogers - Dutch Ruppersberger: Investigative Report on the Terrorist Attacks on U. S. Facilities in Benghazi, Libya, September 11-12, 2012. U.S. House Representatives, $113^{\text {th }}$ Congress, November 21, 2014. http:/intelligence.house.gov/sites/intelligence.house.gov/files/documents/benghazi\%20report.pdf ; Review of the Terrorist attacks on U.S. Facilities in Benghazi, Libya, September 11-12, 2012. Together with additional views, Senate Select Committee on Intelligence. United States Senate, $113^{\text {th }}$ Congress, January 15, 2014. http://www.intelligence.senate.gov/sites/default/files/press/benghazi.pdf

11 Global Terrorism Index Report 2014 - Measuring And Understanding The Impact Of Terrorism. Reliefweb.int, 16 Nov, 2014. http://reliefweb.int/report/world/global-terrorism-index-report-2014
} 
beszéltünk arról, hogy a gyújtogatásoknak, nagy tüzeknek mindig jelentős hírértékük van, ami szintén vonzza a terroristákat.

\section{Az al-Kaida és az erdőtüzek}

A tüz terror részekénti bevetésén az al-Kaida is gondolkodott. Már 2003-ban készült egy FBI-jelentés, amely arról szólt, hogy a bebörtönzött al-Kaidavezetők arról értekeztek, hogyan lehetne erdőtüzeket előidézni gyújtogatással az Egyesült Államok nyugati államaiban (Colorado, Montana, Utah és Wyoming). A terroristák úgy gondolták, ha kiderülne, hogy a jelentős anyagi károkat okozó erdőtüzek nem természeti katasztrófák, hanem jó szervezett terrortámadás részei, akkor az amerikai állampolgárok arra kényszeríthetik a kormányzatot, hogy változtasson a politikáján. ${ }^{12} \mathrm{~A}$ terrorszervezet egyik vezetője, Kálid Sejk Mohamed úgy gondolta, hogy teljesen felesleges egy igen költséges, piszkos bombát szereznie a szervezetnek, hiszen ha gázzal vagy más gyúlékony anyaggal megtöltött tartálykocsikkal mondjuk, New Yorkban belehajtanak húsz különböző fontos középületbe vagy bevásárlóközpontba, az legalább annyi áldozattal, hírveréssel jár, ráadásul megingathatnák az állampolgárok bizalmát a kormányzatban. ${ }^{13}$ 2004-ben egy arab nyelvủ radikális iszlamista honlapon a szervezet újabb hatpontos tervvel rukkolt elö arról, hogyan lehetne gyújtogatással támadást intézni amerikai célpontok (erdők, repterek, olajfinomítók stb.) ellen. A tervben új elemként jelent meg az élelmiszergyártásba való beavatkozás, hogy élelmiszereket fertőzhessenek, mérgezhessenek meg. ${ }^{14} \mathrm{~A}$ terrorszervezet később is visszatért a számára oly kedves témához, mint ahogy az általuk müködtetett Inspire magazin is bizonyítja. A magazin 2010-ben megjelenő első számában már erdőtüzek létrehozására buzdítja a dzsihád részeként gyújtogatni kívánókat. A témával behatóbban azonban csak a 2012-ben megjelenő kilencedik számában foglalkozott. A cikk írója egy terjedelmes írásban értekezett arról, hogy hogyan lehet Amerikában, Ausztráliában vagy Európában mesterségesen erdőtüzeket elő-

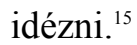

\footnotetext{
12 Joseph Farah: Terrorist plotted setting U.S. Fires. WND.com, 10. 29, 2007. http://www.wnd.com/2007/10/44266/

13 Robert A. Baird: i. m.

14 New al-Qaida plot to burn U.S. forests. WND.com, 04. 08, 2004. http://www.wnd.com/2004/04/24086/

15 https://ia801603.us.archive.org/6/items/inspr1to10/Inspire_9.pdf
} 
A cikk szerzője azzal kezdi, hogy ismerteti a 2002 decemberében kitörö ausztráliai tüzvészt, amely az országban az elmúlt harminc év legveszélyesebb és legnagyobb tüzének számított. A tüzzel napokig küzdött 4500 tüzoltó, akiket tüzoltásra alkalmas repülőgépek segítettek. Ennek ellenére a tüz elérte Sydney-t, ahol több száz ház égett le. A szakemberek szerint a tüz ereje huszonhárom nukleáris bombáéval ért fel. A cikk írója szerint Amerikában hasonló tüzek keletkeztek, főleg Montanában, ami amúgy gyorsan fejlődő terület. A tanulmány szerint a terroristák a természet változásait (szárazság, nagy kiterjedésü erdők stb.) kihasználva képesek egy halálos hatékonyságú „tüzbombát” létrehozni, amellyel az általuk gyülölt nyugatiakra mérhetnek csapást. Éppen ezért a tüzet „Allah egyik harcosának” nevezi a későbbiekben. Három fontos dolgot tart a siker kulcsának, Allah segítségét, a megfelelően kiválasztott helyet és időt, illetve a megfelelően elkészített és müködő gyújtóbombát. A tanulmány külön megemlíti, hogy egy Ausztrália északi területein történő gyújtogatásos merénylethez a legjobb a tavaszi időszak, míg a délebbi régiókban inkább a nyár javasolt. Értekezik még a szél fontosságáról, mivel az jelentősen növelheti a pusztítás mértékét, és akár lehetetlenné is teheti a tüzoltók munkáját. A szerzö külön említi az erdök összetételét, illetve hogy azokban milyen tüzet érdemes gyújtani, illetve ehhez milyen gyújtóeszközöket érdemes használni. Ezek után pedig ismerteti a különböző időzítésű gyújtóbombák elkészítésének és használatának módjait, amelyekkel erdőtüzek okozhatók. Persze emellett olyan „ósdi” technikákat is bemutat, mint a cigarettával, lencsével való tüzgyújtás. Ezek után foglalkozik a támadások helyének megválasztásával, elsősorban az Egyesült Államok, Nagy-Britannia, Izrael, illetve a NATO- tagállamok területén, és mindazon országokban, amelyek az említettekkel bármilyen szövetségben állnak. Azonban a muzulmán országok nem lehetnek célpontok, illetve az említett országokban élő muzulmánok sem, csak a cikk szerzője szerint hitetlenek (mindenki, aki nem muzulmán). A támadások előkészítésében fontos szerepet szán az időjárás-elörejelzéseknek, a tudományos magazinokban megjelenő, egy-egy terület éghajlatával, környezetével foglalkozó cikkeknek. Külön jelzi az internet fontosságát a célpont megválasztásában. Ha megvan a kiválasztott hely, akkor el kell helyezni a bombákat, lehetőleg úgy, hogy azok minél nagyobb pusztítást okozzanak (lakóházak közelében, egyszerre többfelé az erdőben stb.). Külön felhívja a reménybeli gyújtogatók figyelmét arra, hogy legalább harminc gyújtóbombát készítsenek egy erdő felgyújtásához, mert csak akkor van esélye a sikeres terrortámadásnak. A támadások elsődleges egyik céljának a minél nagyobb mértékủ anyagi kár okozását tartja. Megemlíti például, hogy 2009-ben egy kaliforniai tüzvész miatt több mint kétmilliárd amerikai 
dollár kár keletkezett. A cikkíró emellett fontosnak tartja az emberi életek elvételét is, de nem azok nagy száma miatt, hanem mert a megtámadott közösség ezzel is terrorizálható. Itt egy chilei esetet említ meg, amikor a védekezésben részt vevő tüzoltók közül heten meghaltak a tüzben, ez pedig sokkolta a helyieket. Külön kiemeli, hogy Kálid Sejk Mohamed sikerének is az volt az egyik titka, hogy képes volt az ellenfeleit terrorizálni, és félelmet ültetni a szívükbe. A tanulmány végén a szerző annak a véleményének ad hangot, hogy az említett tüzeket még modern eszközökkel sem lehet sikeresen megfékezni, mivel azt Allah a pusztításra teremtette. A tanulmány külön megemlíti a palesztin alMasadah Jihadi Brigades (Masada al-Mujahideen) terrorszervezet tagjait, akik izraeli célpontok ellen több esetben is sikeresen hajtottak végre gyújtogatásos merényleteket. ${ }^{16} \mathrm{~A}$ tanulmány utóéletéhez hozzátartozik, hogy Kalifornia állam szakhatóságai megvizsgálták az Inspire Magazinban javasolt gyújtóbombák müködését, de nem találták elég hatékonynak öket. ${ }^{17}$ Ennek ellenére több információ is alátámasztja, hogy a terroristák sikeresen alkalmazták a tüzet fegyverként, és továbbra is az eszköztárukban kívánják tartani. Ezt bizonyítja egy másik jelentés, amit több hírszerzéssel, belbiztonsággal foglalkozó szervezet jegyez. Ebben valós veszélyként tüntetik fel, hogy a terroristák gyújtogatással próbálnak terrortámadásokat végrehajtani Amerika területén. ${ }^{18}$ Egyébként nem az al-Kaida foglalkozott először azzal a kérdéssel, hogy az erdőtüzek hogyan használhatók fel a terror eszközeként, például az amerikai hadsereg őrnagya, Robert Arthur Baird ${ }^{19}$, illetve az ausztrál Mervyn F. Bendle igyekezett felhívni a figyelmet erre a veszélyre. ${ }^{20}$

\section{Szándékosan okozott terrorgyanús erdőtüzek}

2003 júliusában, a francia Riviérán található Roquebrune-sur-Argens közelében ismeretlenek Molotov-koktélokkal szándékosan gyújtották fel az erdőt,

\footnotetext{
16 David Barnett: Palestinian jihadist group claims credit for Arizona wildfire. LongWarJournal.com, July 3, 2013. http://www.longwarjournal.org/archives/2013/07/masadat_al_mujahideen_claims_c.php

17 A practical test of the "ember bomb" as described. Inspire, issue 9, 1 June 2012. https://info.publicintelligence.net/STAC-EmberBombTest.pdf

18 Terrorist Interest in Using Fire as a Weapon. Homeland Security, 31 May 2012. https://info.publicintelligence.net/DHS-TerroristFireWeapon.pdf

19 Robert A. Baird: i. m.

20 Mervyn F. Bendle: Australia's nightmare: bushfire jihad and pyro terrorism. National Observer, no. 79, 2008/09, pp. 8-22. http://www.nationalobserver.net/pdf/2009_australias_nightmare_bushfire_ jihad_and_pyroterrorism.pdf
} 
négy ember halálát okozva. Emellett jelentős anyagi kár keletkezett, illetve több mint tízezer embert ki kellett telepíteni a veszélyeztetett területről. A francia hatóságok terrorcselekményként kezelték az ügyet. ${ }^{21}$ Izraelben a palesztinok már korábban is használták a tüzet a terrortámadásaikban, de 2004ben gyújtottak fel először erdőket, hogy minél nagyobb kárt okozzanak, és a kormány ellen fordítsák a lakosságot. ${ }^{22} \mathrm{Az}$ izraeliek gyújtogatásos intifádának nevezték el a támadásokat. ${ }^{23}$ A 2007 -es nagy pusztítással járó görögországi erdőtüzeknél is felvetődött a terrorcselekmény gyanúja, mivel egyértelmüen bebizonyosodott, hogy a tüzeket gyújtogatás okozta. Az időzítő/indító szerkezet maradványait is megtalálták. A görög és más külföldi hírszerzői értesülések szerint a gyújtogatás hátterében az al-Kaida és a hozzá köthető csoportok állhattak, amelyek az országra nemcsak logisztikai bázisként, de NATO-tagországként is célpontként tekintettek. A görög határőrség le is tartóztatott egy szaúdi férfit, akinél a robbantáskor használt szerkezetekhez hasonlókat találtak. ${ }^{24}$

2012 októberében az orosz titkosszolgálat vezetöje, Alekszandr Bortnyikov azt állította, hogy az abban évben bekövetkező európai erdőtüzek egy részét az al-Kaida emberei okozták, egy terrorcselekmény-sorozat részeként. Bortnyikov szerint az ,alacsony költségü” terrortámadások az al-Kaida új európai stratégiájának részei. ${ }^{25}$ Bár bizonyítani nem lehet, hogy az általa említett erdőtüzekért biztosan terroristák a felelösek, de a következő években több nagyobb tüzvészről egyértelmüen kiderült, hogy azok gyújtogatás következményei. Az egyik ilyen nagyszabású tűz a coloradói Black Forestben tört ki 2013. június 11-én, e miatt harmincnyolcezer embert kellett kitelepíteni, a tüzvészben két ember veszítette életét, 489 ingatlan teljesen megsemmisült, és több mint hat hektár erdő teljesen leégett. A kár teljes értéke 420,5

\footnotetext{
21 Britons killed in 'terrorist' forest fires. The Telegraph, 29 Jul 2003. http://www.telegraph.co.uk/news/1437457/Britons-killed-in-terrorist-forest-fires.html

$22 \mathrm{Az}$ izraelieket igen érzékenyen érintették a gyújtogatásokból kialakuló erdőtüzek. Nemcsak a leégett területek, illetve az anyagi kár jelentős mértéke miatt, hanem azért is, mert az évszázadok óta elsivatagosodott, használhatatlan területeket ők tették termővé a saját kezükkel, illetve ők telepítették viszsza az erdőségeket. Éppen ezért ezek az események hatalmas pszichikai nyomást gyakoroltak az izraeli lakosságra. A kormányzat még inkább elkötelezte magát nemcsak a leégett területek újrafásítására, de újabb erdőségek telepítésére is.

23 Robert A. Baird: i. m.

24 Ioannis Michaletos - Christopher Deliso: New Security Threats, Trends in Global Intelligence Influence Greek Reforms. Balkanalysis.com, February 16, 2008. Balkanalysis.com, February 16, 2008. http://www.balkanalysis.com/blog/2008/02/16/new-security-threats-trends-in-global-intelligence-influence-greek-reforms/

25 Meira Svirsky: Russian Intel: Militant Groups Setting Forest Fires in Europe. Clarionproject.org, October 31, 2012. http://www.clarionproject.org/news/fire-one-soldiers-allah\#
} 
millió amerikai dollár volt. ${ }^{26}$ 2013-ban Arizonában is hatalmas erdőtüz pusztított, ráadásul a jelentős anyagi károk mellett 19 tüzoltó is meghalt. ${ }^{27} \mathrm{Ez}$ a tüzeset azért is érdekes, mivel azt egy az al-Kaidához közel álló palesztin terrorszervezet vállalta magára. Ennek ellenére sokan szkeptikusan fogadták a szervezet hivatalos közleményét, és inkább az időjárást, illetve a véletlent okolják a tüz keletkezéséért. ${ }^{28}$

\section{A 2016-os izraeli tüzek}

Az első tüzek 2016. november 21-én, hétfőn lobbantak fel a Jeruzsálem és Tel-Aviv között található Nevé-Salom településen, nem sokkal ezután a Haifától alig harminc kilométerre északra található Zihrón-Jaakov településen, majd a tüzek átterjedtek Izrael középső és északi területeire, amelyeket az izraeli tüzoltók a hadsereg ${ }^{29}$ és a rendőrség egységeivel közösen igyekeztek felszámolni. ${ }^{30}$ A több napig tartó küzdelemben a közvetlen életveszély miatt emberek tízezreit kellett kitelepíteni a lakóhelyükröl. November 23-án például Nataf városa lángolt, és a hatóságoknak hamarosan Izrael harmadik legnagyobb városát, Haifát is ki kellett üríteniük, ahonnan több mint hatvanezer embert menekítettek ki a lángok elől. ${ }^{31} \mathrm{~A}$ városból nemcsak a lakosok egy része menekült el, de közintézményeket, egyetemeket, iskolákat, sőt még a börtönöket is evakuálni kellett. Az otthonukat elhagyókat sportcsarnokokban, közintézményekben helyezték el, míg az otthon maradókat a város polgár-

26 Black Forest Fire 11-21 2013. After Action Report/Inprovement Plan. El Paso County, Colorado Sheriff's Office, 15 May 2014.

http://wildfiretoday.com/documents/Black_Forest_Fire_EPSO_AA_Report.pdf

27 Dave Urbanski: 'Terrible, Terrible Dark Day in Arizona': 19 Firefighters Perish Battling Deadliest U.S. Wildfire in 30 Years. The Blaze, June 30, 2013.

http://www.theblaze.com/stories/2013/06/30/official-18-arizona-firefighters-dead-after-battlingblaze/

28 David Barnett: i. m.

$29 \mathrm{Az}$ izraeli hadsereg két kutató-mentő zászlóaljat, valamint mozgósított tartalékosokat vetett be a tüzek megfékezésére. Ruth Eglash: 60,000 Israelis evacuated in Haifa as fires continue to rage. The Washington Post, November 24, 2016.

https://www.washingtonpost.com/news/worldviews/wp/2016/11/24/five-countries-help-israel-fightmassive-fires/?utm_term=.7cbb2790ef94

30 Később kiderült, hogy az első tüz keletkezésének az oka szándékos gyújtogatás volt. Andrew Carey Laura Smith-Spark: Israel wildfires: Haifa residents back home; fires under control. CNN, November 25, 2016. http://edition.cnn.com/2016/11/25/middleeast/israel-wildfires-haifa-evacuation/

31 Wildfires tear across Israel, Netanyahu calls arsonists 'terrorists'. Reuters, 25 Nov 2016. http://www.cnbc.com/2016/11/25/wildfires-tear-across-israel-netanyahu-calls-arsoniststerrorists.html 
mestere a tüzoltásban történő minél nagyobb számban való részvételre kérte fel. A helyi lakosok a mostani helyzetet sokkal veszélyesebbnek tartották, mint a 2010-es Kármel hegyi tüzvészt, amely három napig tartott, és amelyben negyvennégyen haltak meg. ${ }^{32}$ Egyes beszámolók szerint a mostani tüzvészben többméteres lángokkal küszködtek a tüzoltók. ${ }^{33}$ Ezt a The Guardian fotóriportere által készített képek is bizonyítják, ezeken látható, hogy nemcsak az erdőkben, de a lakótelepeken is hatalmas tüzek lángolnak. ${ }^{34} \mathrm{~A}$ tüz nagyságát jól szemlélteti, hogy a Jeruzsálemet Tel-Avivval összekötő 443-as autópályát is le kellett zárni, mivel a tüz a pálya mellett található Modin városát is elérte. ${ }^{35}$ Sőt a lángok Jeruzsálemet is veszélyeztették, így a város közvetlen közelében található Bét Meir település lakosait evakuálni kellett. ${ }^{36}$ Bár a tüzek nagy részét péntekre sikerült megfékezni, még vasárnap is volt feladatuk a tüzoltóknak. A haifai lakosság nagy része már pénteken visszatérhetett az otthonába, az evakuáltak több településen azonban elővigyázatosságból még az ideiglenes szállásokon maradtak. ${ }^{37}$

A különböző helyeken sorban felgyulladó tüzek terjedését az időszakhoz képest szokatlanul száraz időjárás (az országban hónapok óta nem esett eső) és a sokszor viharos erejü szél is elősegítette, így a védekező egységek képtelenek voltak minden helyszínen helytállni, ezért az ország kormányföje, Benjamin Netanjahu a nemzetközi közösséghez fordult segítségért. A felhívására szinte azonnal reagált Bulgária, Ciprus, Horvátország, Franciaország, Görögország, Olaszország, Oroszország, Románia, Spanyolország és Törökország $^{38}$, és tüzoltására alkalmas repülőgépeket, eszközöket és képzett tüzol-

32 A 2010-es tüzvész után az arab lakosok közül többen szándékosan gyújtogattak, de az izraelieknek sikerült megfékezniük a tüzeket. Yaakov Lappin: Police: Usfiya boy, 14, admits to starting Carmel fire. The Jerusalem Post, 12. 06, 2010. http://www.jpost.com/National-News/Police-Usfiya-boy-14admits-to-starting-Carmel-fire

33 Tens Of Thousands flee bush fires as Israel alleges 'arson terror'. Daily Nation, November 25, 2016. http://www.nation.co.ke/news/world/Thousands-flee-bushfires-as-Israel-alleges—arson-terror-/10683464192-2kdawgz/

34 Joanna Ruck: Forest fires in Israel - in pictures. The Guardian, 24 November 2016. https://www.theguardian.com/world/gallery/2016/nov/24/wildfires-in-israel-in-pictures

35 Israel fires: Tens of thousands flee as fires hit Haifa, BBC News, 24 November 2016, http://www.bbc.com/news/world-middle-east-38088651

36 Israel fires: Netanyahu says 'arson is terror' as Palestinians help tackle blazes. Middle East Eye, 25 November 2016. http://www.middleeasteye.net/news/arson-terror-warns-netanyahu-palestinian-firefighters-help-tackle-israel-wildfires-1983681925

37 Andrew Carey - Laura Smith-Spark: i. m.

38 Ciprus és Görögország négy tüzoltásra alkalmas repülőgépet és 49 tüzoltót küldött, illetve repülőgépeket küldött még Oroszország, Nagy-Britannia, Horvátország, Olaszország és Törökország is. Forest fire in Israel: arrests and foreign help. Fact International, November 26, 2016. $\mathrm{http} / /$ fact.international/2016/11/forest-fire-in-israel-arrests-and-foreign-help/ 
tókat küldtek az izraeli lakosság megsegítésére. Az oroszok például küldtek két Beriev Be-200 típusú gépet, amelyek egyszerre tizenkétezer liter vízzel képesek oltani, és ezt a mennyiséget tizennégy másodperc (!) alatt töltik fel. A javuló török-izraeli kapcsolatok jegyében a török kormány is egy tüzoltásra kialakított repülőgépet küldött Izraelbe. A kormányfő külön megkereste az Egyesült Államok elnökét, hogy kölcsönkérjen egyet a 747-es típusú szupertankerekből, amelyek az egyre gyakoribb amerikai erdőtüzek oltásakor már bizonyították az alkalmasságukat, illetve felszereltségük miatt akár huszonnégy órán át folyamatosan, azaz éjjel is képesek a tüzek oltására. Hamarosan a Palesztin Hatóság is felajánlotta a segítségét a tüzek megfékezésére ${ }^{39}$, sőt az ország arab szomszédjai közül Egyiptom és Jordánia is küldött segítséget. ${ }^{40}$

Azonban hamarosan felvetődött a szándékos gyújtogatás gyanúja is, amely több esetben is beigazolódni látszott. Ezután az ország miniszterelnöke egy Haifában megtartott sajtótájékoztatón kijelentette, hogy minden szándékosan elkövetett gyújtogatást terrorcselekményként bírálnak el, illetve a gyújtogatókat terroristaként kezelik. A miniszterelnök szerint aki ,,az ország bármelyik pontján gyújtogatni próbál, az nem marad büntetlenül" "4l. Az ország belügyminisztere, Gilad Erdan ,gyújtogatásos terrorizmusnak” nevezte az eseményeket, és jelezte, hogy az izraeli biztonsági erők több gyújtogatót is letartóztattak, sőt egy a katonai rádióban tett nyilatkozatában ennél is tovább ment, mivel szerinte a keletkezett tüzek legalább felét gyújtogatás okozta. ${ }^{42}$ A gyújtogatás tényét Roni Alsheikh rendőrparancsnok is megerősítette, és jelezte, hogy külön nyomozó csoport foglalkozik azok kivizsgálásával, de a téma érzékenysége miatt ő sem bocsátkozott további részletekbe. ${ }^{43}$ A szándékos gyújtogatás tényét erősítette meg a haifai tüzoltóság parancsnoka, Simon Ben Ner is, aki egy rádiónyilatkozatában arról beszélt, hogy magát a tüzoltóállomást is fel akarták gyújtani, hogy ezzel is hátráltassák/megakadályozzák a tüzoltók tevékenységét. ${ }^{44}$ Pénteken az izraeli rendőrség szóvivője, Micky Rosenfeld bejelentette, hogy szándékos gyújtogatás vádjával tizenkét embert

\footnotetext{
39 A Palesztin Hatóság nyolc tüzoltó kocsival és azok legénységével vett részt a Haifa környéki tüzek oltásában. Andrew Carey - Laura Smith-Spark: i. m.

40 Michael M. Roesen: Israel on Fire. National Review, November 30 2016. http://www.nationalreview.com/article/442557/israeli-fires-hope-amid-flames

41 Israel fires: Netanyahu says... i. m.

42 Tens Of Thousands flee... i. m.

43 Forest fire in Israel: arrests... i. m.

44 Anna Ahronheim: As Israel burns, are we looking at a new form of eco-terrorism? The Jerusalem Post, 11/24/2016. http://www.jpost.com/Arab-Israeli-Conflict/Are-we-looking-at-a-new-form-of-terrorism-473566
} 
tartóztattak le, majd ezt további letartóztatások követték. ${ }^{45}$ Mind ez idáig harmincöt letartóztatást hajtottak végre az izraeli hatóságok. ${ }^{46} \mathrm{Az}$ eddigi vizsgálatok során több esetben találtak gumi- és Molotov-koktél-maradványokat a tüzek helyszínén, sőt néhány gyújtogatót sikerült tetten érni ${ }^{47}$ David Bukay, a Haifai Egyetem professzora, az izraeli-palesztin konfliktus szakértője, egy vele készített interjúban kijelentette, hogy Haifában négy olyan tüzesetről tud, amelyek hasonló módon, szinte egy időben kezdődtek a város egymástól távol eső pontjain. Ezeket egyértelmüen szándékos gyújtogatásnak tartotta. ${ }^{48} \mathrm{Az}$ Algemeiner riporterének információja szerint a tüzesetek hatvan százalékában bizonyítható az idegenkezüség, de az erre vonatkozó pontos információk csak a hatósági vizsgálat befejezése után megismerhetők. ${ }^{49}$

Egyre többen beszélnek a „tüzintifádáról” mint a palesztinok egyik új fegyveréröl az izraeliek ellen. Ezzel kapcsolatban azonban visszafogottságra int Boaz Ganor, a Nemzetközi Terrorelhárítási Intézet (International Institute for Counter-Terrorism; ICT) alapítója és vezetöje, aki egyértelmüen terrorcselekménynek tartja a gyújtogatásokat, amelyekkel a sürün lakott területek lakóit, vagy a nagyobb, összefüggő erdőségeket veszélyeztetik a gyújtogatók. Azonban szerinte nem szabad túlértékelni ezeket a támadásokat. A szakértő szerint a terroristák nemcsak Izraelben, de máshol is gyakran használják fel a tüzet fegyverként terrorcselekmények során ${ }^{50}$, ezért nem tekinthetö új fegyvernek. ${ }^{51}$ Ennél keményebben fogalmazott Yoram Schweitzer, izraeli terrorizmus-szakértö, aki szerint botorság a „tüzintifáda” kifejezést használni, legalábbis addig nem megalapozott, míg a tüzeseteket teljeskörúen ki nem vizsgálták. ${ }^{52}$

\footnotetext{
45 Andrew Carey - Laura Smith-Spark: i. m.

46 Anatomy of a firestorm: 180 injured, hundreds of homes in ruins, 33,000 dunams of parkland burned. The Times of Israel, November 27, 2016. http://www.timesofisrael.com/anatomy-of-a-firestorm-over180-injured-hundreds-of-homes-destroyed-33000-dunams-of-national-park-consumed/

47 Michael M. Roesen: i. m.

48 Elad Benari: Arab world celebrates fires in Israel. "Israel is burning" becomes a popular hashtag on Twitter as Arabs rejoice in Israel's fires. Arutz Sheva, 25/11/16. http://www.israelnationalnews.com/News/News.aspx/220824

49 Ruthie Blum: Report: 'Arson Terrorism' Behind at Least $60 \%$ of Fires Raging Across Israel. The Algemeiner, November 24, 2016. https://www.algemeiner.com/2016/11/24/report-arson-terrorismbehind-at-least-60-of-fires-raging-across-israel/

50 Daniel Pipes: Bushfire Jihad. Daniel Pipes Blog, Mar 26, 2009. http://www.danielpipes.org/blog/2009/03/bushfire-jihad-in-australia

51 Mint korábban is jeleztem, a palesztin al-Masadah Jihadi Brigades (Masada al-Mujahideen) terrorszervezet több alkalommal hajtott végre izraeli célpontok ellen gyújtogatásos merényleteket. Ugyanez a szervezet az Amerikai Egyesült Államokban bekövetkezett más erdőtüzek szándékos okozását is magára vállalta. David Barnett: i. m.

52 Anna Ahronheim: i. m.
} 
Egyes feltételezések szerint a gyújtogatásokat az válthatta ki, hogy az izraeli hatóságok rendeletben tiltották meg, hogy a mecsetekben a müezzinek mikrofonokat használjanak, és azokon keresztül hívják imára a híveiket. A tüzvész előtti héten a Hamász vezetője, Hálid Mesal úgy fogalmazott, hogy az izraeliek a tüzzel játszanak, és nemcsak a palesztinok, de a teljes iszlám világ reakcióival kell számolniuk.

Az izraeli tüzeseteket nemcsak a palesztinok, de több arab ország állampolgárai is ,„üdvözölték”, azokat nagy örömmel fogadták. ${ }^{53}$ Az egyik legelterjedtebb hashtag a Twitteren az \#Israelisburning volt. A közösségi médiákban nemcsak hogy örültek az országot sújtó tüzvésznek, de biztatták a palesztinokat, hogy menjenek és gyújtogassanak. Az egyik twitterező a gyújtogatásokat az izraeliekkel szembeni ellenállás eszközének nevezte. Mások isteni büntetésként tekintették a tüzet, de volt olyan cinikus hozzászóló is, aki a tüzesetet egy jó partilehetöségnek tekintette, egy munkával töltött hét után. ${ }^{54}$ Sokan Hitlert éltették, és az izraeliek halálát kívánták. ${ }^{55}$ Ezek után kevésbé meglepö, hogy egy palesztin újságíró, Anas Abu Daabes egy Facebook-bejegyzésében a tüzvészt isteni büntetésnek tekintette, és arra szólította fel a palesztinokat, hogy vegyenek részt a gyújtogatásban. Ezért a biztonsági erők büncselekményre való felbujtásért letartóztatták. ${ }^{56}$

Függetlenül a tüzek kialakulásától és az ezzel kapcsolatos arab reakcióktól, többen bírálták a kormányzatnak a túzvész kezelésével kapcsolatos tevékenységét, már csak azért is, mivel a 2014-es tüzvészkor a miniszterelnök megígérte, hogy sokkal komolyabban fogják kezelni az erdőtüzek kérdését, és az ellenük való védekezésre sokkal több forrást nyújtanak. ${ }^{57} \mathrm{Ez}$ részben meg is valósult, hiszen a 2016-os évben a tüzoltóság számára több repülőgépet és tüzoltóautót is beszereztek, de úgy tünik, még ez is kevés volt. A 2010-

53 Ananya Roy: Israel is burning: Arab social media flooded with inflammatory messages celebrating deadly wildfire. International Business Times, November 25, 2016. http://www.ibtimes.co.uk/israelburning-arab-social-media-flooded-inflammatory-messages-celebrating-deadly-wildfire-1593371

54 Ruthie Blum: Palestinians, Arab World Celebrate, Take Credit for Israeli Fires With \#IsraelIsBurning Hashtag. The Algemeiner, November 24, 2016. https://www.algemeiner.com/2016/11/24/palestiniansarab-world-celebrate-take-credit-for-israeli-fires-with-israelisburning-hashtag/

55 Seth J. Frantzman: Revealed: Arabic social media support for fires and arson in Israel. Terraincognita, November 27, 2016. https://sethfrantzman.com/2016/11/27/revealed-arabic-social-media-supportfor-arson-in-israel/

56 Israel fires: Netanyahu says... i. m.

57 Nir Hasson: Forest Fires in Israel Will Only Get Worse in Coming Years, Experts Warn. Haaretz, Nov 30, 2016. http://www.haaretz.com/israel-news/1.755665 
es események is hasonlóan zajlottak le, és ott is csak több nap után, jelentős külföldi segítséggel lehetett megfékezni a tüzeket. ${ }^{58}$

A 2016 novemberében majd egy hétig tartó tüzvész mérlege szinte sokkolta az izraelieket. A nyolc napig tartó müveletben több mint 1773 tüzet fékeztek meg, amelyek azonban jelentős károkat okoztak. ${ }^{59}$ Az izraeli jelentések eddig 180 sebesültről és hatalmas anyagi károkról tudósítanak, a kis ország erdőségeinek jelentős része a lángok martaléka lett, valamint legalább ezer lakás is ${ }^{60}$, amelyböl hétszáz Haifában található. ${ }^{61}$

\section{Konklúzió}

Az izraeli eseményekre Európában sokan csak legyintenek, de a gyújtogatásos terrortámadások lehetőségével nemcsak az Egyesült Államoknak, vagy Izraelnek, de Spanyolországnak, Portugáliának, Görögországnak, Olaszországnak, vagy éppen Franciaországnak is határozottan kell számolnia. Ugyanis számukra is súlyos gazdasági és biztonsági próbatételeket jelentenek az erdőtüzek, éppen ezért ez a fenyegetés nem hagyható figyelmen kívül. Az elmúlt évek egyre szárazabb időjárása miatt azonban más államok, köztük hazánk is veszélyeztetett lehet, ezért az ilyen eshetőségekkel nekünk is számolnunk kell. Fontos, hogy az ilyen esetekre a kormányzati szerveknek fel kell készülniük, ajánlott terveket készíteni az érintett szervezetek (nemzeti parkok, tüzoltóság, rendőrség, közigazgatás, lakosság által létrehozott társadalmi szerveződések stb.) bevonásával.

Az erdőtüzek mellett más gyújtogatásos támadásokra is fel kell készülnünk, amelyeknek a célpontjai kormányzati vagy a lakosság által használt kereskedelmi vagy szabadidőközpontok lehetnek. Ezek ellen nemcsak a kormányzatnak, hanem az üzemeltetőknek is fel kell készülniük, aktualizálni és erősíteni kell a különböző biztonsági protokollokat, terveket, megfelelő képesítéssel felvértezett szakembereket kell alkalmazni, illetve az itt dolgozókat folyamatosan kell képezni az ilyen típusú terrortámadások esetleges kezelésére.

\footnotetext{
58 Paul Colsey - Kevin Flower: Dozens killed in northern Israel forest fire. CNN, December 3, 2010. http:/edition.cnn.com/2010/WORLD/meast/12/02/israel.forest.fires/

59 Andrew Friedman: Israel thanks foreign fire crews from Russia, Spain, Egypt, PA, more. Breaking Israel News, November 30, 2016. https://www.breakingisraelnews.com/79366/israel-thanks-foreignfire-crews-russia-turkey-egypt-pa/\#KRjgGE5itC6KVRDT.97

60 Michael M. Roesen: i. m.

61 Andrew Carey - Laura Smith-Spark: i. m.
} 
Magyarországon készült már ugyan egy-egy tanulmány az ilyen típusú terrortámadások esetleges kezeléséről ${ }^{62}$, illetve a kritikus infrastruktúra védelméről, mégis úgy vélem, hogy ezzel a feladattal mélyrehatóbban kell foglalkoznunk. Szintén fontos kérdés, hogy egy ilyen esetben hogyan lehet a Magyar Honvédséget és a most szerveződő területvédelmi (tartalékos) erőket hatékonyan bevonni az effajta támadások következményeinek felszámolásába, illetve esetleg újabb támadások megakadályozására.

\section{IRODALOM}

A practical test of the "ember bomb" as described. Inspire, issue 9, 1 June 2012.

Ahronheim, Anna: As Israel burns, are we looking at a new form of eco-terrorism? The Jerusalem Post, 11/24/2016.

Anatomy of a firestorm: 180 injured, hundreds of homes in ruins, 33,000 dunams of parkland burned. The Times of Israel, November 27, 2016.

Baird, Robert A.: Title: Pyro-Terrorism. The threat of arson induced forest fires as a future terrorist weapon of mass destrucion. 2005. http://www.dtic.mil/dtic/tr/fulltext/u2/a509220.pdf

Barnett, David: Palestinian jihadist group claims credit for Arizona wildfire. LongWarJournal.com, July 3, 2013.

Benari, Elad: Arab world celebrates fires in Israel. "Israel is burning" becomes a popular hashtag on Twitter as Arabs rejoice in Israel's fires. Arutz Sheva, 25/11/16.

Bendle, Mervyn F.: Australia's nightmare: bushfire jihad and pyro terrorism. National Observer, no. 79, 2008/09.

Blum, Ruthie: Palestinians, Arab World Celebrate, Take Credit for Israeli Fires With \#IsraelIsBurning Hashtag. The Algemeiner, November 24, 2016.

Blum, Ruthie: Report: 'Arson Terrorism' Behind at Least 60\% of Fires Raging Across Israel. The Algemeiner, November 24, 2016.

Bradley, Ed: Burning Rage - eports On Extremists Now Deemed Biggest Domestic Terror Threat. CBS News, Nov. 13, 2005. http://www.cbsnews.com/news/burning-rage/ Britons killed in 'terrorist' forest fires. The Telegraph, 29 Jul 2003.

Burton, Fred - Stewart, Scott: China: An Outside-the-Box Terrorist Plot? Stratfor, Mar 19, 2008.

Carey, Andrew - Smith-Spark, Laura: Israel wildfires: Haifa residents back home; fires under control. CNN, November 25, 2016.

\footnotetext{
62 Lásd például Csutorás Gábor: Terrortámadásból származó tüzek oltása katonai repülőtereken. Hadtudomány, 2008. november. http://www.mhtt.eu/hadtudomany/2008/3_4/110-121.pdf ; Létai János: A tűzoltás és az életmentés sajátosságai a kelet-nyugati metróvonal alagútjában. Szent István Egyetem Ybl Miklós Építéstudományi Kar Tüzvédelmi és Biztonságtechnikai Intézet, 2009.

http://www.vedelem.hu/letoltes/anyagok/590-a-tuzoltas-es-az-eletmentes-sajatossagai-a-kelet-nyugati-metrovonal-alagutjaban.pdf
} 
Colsey, Paul - Flower, Kevin: Dozens killed in northern Israel forest fire. CNN, December 3, 2010.

Csutorás Gábor: Terrortámadásból származó tüzek oltása katonai repülőtereken. Hadtudomány, 2008. november

Eglash, Ruth: 60,000 Israelis evacuated in Haifa as fires continue to rage. The Washington Post, November 24, 2016.

Farah, Joseph: Terrorist plotted setting U.S. Fires. WND.com, 10. 29, 2007.

Forest fire in Israel: arrests and foreign help. Fact International, November 26, 2016.

Frantzman, Seth J.: Revealed: Arabic social media support for fires and arson in Israel. Terraincognita, November 27, 2016.

Friedman, Andrew: Israel thanks foreign fire crews from Russia, Spain, Egypt, PA, more. Breaking Israel News, November 30, 2016.

Hasson, Nir: Forest Fires in Israel Will Only Get Worse in Coming Years, Experts Warn. Haaretz, Nov 30, 2016.

Israel fires: Netanyahu says 'arson is terror' as Palestinians help tackle blazes. Middle East Eye, 25 November 2016.

Israel fires: Tens of thousands flee as fires hit Haifa, BBC News, 24 November 2016,

Jackson, Brian A. - Frelinger, David R.: Rifling Through the Terrorists' Arsenal Exploring Groups' Weapon Choices and Technology Strategies. Rand Corp., 2007

Lappin, Yaakov: Police: Usfiya boy, 14, admits to starting Carmel fire. The Jerusalem Post, 12. 06, 2010.

Létai János: A tűzoltás és az életmentés sajátosságai a kelet-nyugati metróvonal alagútjában. Szent István Egyetem Ybl Miklós Építéstudományi Kar Tűzvédelmi és Biztonságtechnikai Intézet, 2009

Michaletos, Ioannis - Deliso, Christopher: New Security Threats, Trends in Global Intelligence Influence Greek Reforms. Balkanalysis.com, February 16, 2008.

Pfeifer, Joseph W.: Fire as a weapon in terrorist attacks. Combating Terrorist Center, July 23, 2013.

Pipes, Daniel: Bushfire Jihad. Daniel Pipes Blog, Mar 26, 2009.

Roesen, Michael M.: Israel on Fire. National Review, November 30. 2016.

Rogers, Mike - Ruppersberger, Dutch: Investigative Report on the Terrorist Attacks on U. S. Facilities in Benghazi, Libya, September 11-12, 2012. U.S. House Representatives, $113^{\text {th }}$ Congress, November 21, 2014.

Roy, Ananya: Israel is burning: Arab social media flooded with inflammatory messages celebrating deadly wildfire. International Business Times, November 25, 2016.

Ruck, Joanna: Forest fires in Israel - in pictures. The Guardian, 24 November 2016.

Schorn, Daniel: Burning Rage. CBS News, 2005. Nov. 10.

http://www.cbsnews.com/news/burning-rage/

Svirsky, Meira: Russian Intel: Militant Groups Setting Forest Fires in Europe. Clarionproject.org, October 31, 2012. 
Tens Of Thousands flee bush fires as Israel alleges 'arson terror'. Daily Nation, November 25, 2016.

U.S. Senate: Statement of John Lewis Oversight on Eco-terrorism specifically examining the Earth Liberation Front (ELF) and the Animal Liberation Front (ALF).

http://www.iwar.org.uk/cyberterror/resources/eco-terror/lewis.htm

Urbanski, Dave: 'Terrible, Terrible Dark Day in Arizona': 19 Firefighters Perish Battling Deadliest U.S. Wildfire in 30 Years. The Blaze, June 30, 2013.

Walter, Ted: Beyond Misinformation. What Science Says About the Destruction of World Trade Center Buildings 1, 2, and 7. Architects \& Engineers for 9/11 Truth, Inc., Berkeley, 2015 Wildfires tear across Israel, Netanyahu calls arsonists 'terrorists'. Reuters, 25 Nov 2016. 